

\section{Chicana Matters Series \\ Deena J. González and Antonia Castañeda, editors}

Chicana Matters Series focuses on one of the largest population groups in the United States today, documenting the lives, values, philosophies, and artistry of contemporary Chicanas. Books in this series may be richly diverse, reflecting the experiences of Chicanas themselves, and incorporating a broad spectrum of topics and fields of inquiry. Cumulatively, the books represent the leading knowledge and scholarship in a significant and growing field of research and, along with the literary works, art, and activism of Chicanas, underscore their significance in the history and culture of the United States. 


\title{
FERTILE MATTERS
}

\section{The Politics of Mexican-Origin Women's Reproduction}

\author{
ELENA R. GUTIÉRREZ
}

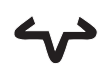

UNIVERSITY OF TEXAS PRESS AUSTIN 
(C) 2008 by the University of Texas Press

All rights reserved

Printed in the United States of America

First edition, 2008

Requests for permission to reproduce material

from this work should be sent to:

Permissions

University of Texas Press

P.O. Box 7819

Austin, TX 78713-7819

www.utexas.edu/utpress/about/bpermission.html

(0) The paper used in this book meets the minimum requirements of ANSI/NISO Z39.48-1992 (R1997) (Permanence of Paper).

Library of Congress Cataloging-in-Publication Data

Gutiérrez, Elena R., 1970-

Fertile matters : the politics of Mexican-origin women's reproduction /

Elena R. Gutiérrez. - 1st ed.

p. cm. - (Chicana matters series)

Includes bibliographical references and index.

ISBN 978-0-292-71681-o (cloth : alk. paper) -

ISBN 978-0-292-71682-7 (pbk. : alk. paper)

1. Fertility, Human-United States. 2. Mexican Americans-

Population. 3. Mexican American women. 4. Involuntary sterilization-United States-History. I. Title. II. Title: Politics of Mexican-origin women's reproduction.

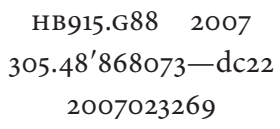


For my parents, Félix Frank Jr. and Maria Elena Gutiérrez 
THIS PAGE INTENTIONALLY LEFT BLANK 